\title{
Evaluation of toxicological and antioxidant potential of Nardostachys jatamansi in reversing haloperidol-induced catalepsy in rats
}

This article was published in the following Dove Press journal:

International Journal of General Medicine

10 May 2010

Number of times this article has been viewed

\author{
A S Rasheed' \\ S Venkataraman' \\ $\mathrm{K} N$ Jayaveera ${ }^{2}$ \\ A Mohammed Fazil ${ }^{3}$ \\ K J Yasodha ${ }^{3}$ \\ $\mathrm{MA}$ Aleem $^{3}$ \\ M Mohammed ${ }^{3}$ \\ Z Khaja ${ }^{3}$ \\ B Ushasri ${ }^{3}$ \\ H A Pradeep ${ }^{3}$ \\ M Ibrahim ${ }^{3}$ \\ 'Department of Pharmacology \\ and Toxicology, C L Baid Metha \\ College of Pharmacy, Jyothi Nagar, \\ Thoraipakkam, Chennai, Tamil Nadu, \\ India; ${ }^{2}$ Department of Chemistry, \\ Jawaharlal Nehru Technology \\ University, Anantapur, Andhra Pradesh, \\ India; ${ }^{3}$ Nizam Institute of Pharmacy \\ and Research Center, Deshmukhi, \\ Pochampally (M), Near Ramoji Film \\ City, Nalgonda, (AP), India
}

\begin{abstract}
An aqueous root extract from Nardostachys jatamansi was investigated for its antioxidant and anticataleptic effects in the haloperidol-induced catalepsy rat model of the disease by measuring various behavioral and biochemical parameters. Catalepsy was induced by administration of haloperidol $(1 \mathrm{mg} / \mathrm{kg}, i p)$ in male albino rats. A significant $(P<0.01)$ reduction in the cataleptic scores were observed in all the drug-treated groups as compared to the haloperidol-treated group; with maximum reduction observed in the Nardostachys jatamansi ( 250 and $500 \mathrm{mg} / \mathrm{kg}$ body weight) administered group. To estimate biochemical parameters: the generation of thiobarbituric acid reactive substances (TBARS); reduced glutathione (GSH) content and glutathione-dependent enzymes; catalase; and superoxide dismutase (SOD), in the brain were assessed. Haloperidol administration increased generation of TBARS and significantly reduced GSH, which were restored to near normal level with the Nardostachys jatamansi treatment. Catalase and SOD levels were also increased to normal levels, having been reduced significantly by haloperidol administration. Our findings of behavioral studies and biochemical estimations show that Nardostachys jatamansi reversed the haloperidol-induced catalepsy in rats. We conclude that the antioxidant potential has contributed to the reduction in the oxidative stress and catalepsy induced by haloperidol administration.
\end{abstract}

Keywords: Nardostachys jatamansi, antioxidant, toxicological, haloperidol and catalepsy

\section{Introduction}

The brain is deficient in oxidative defense mechanisms and hence is at a greater risk of damage mediated by reactive oxygen species (ROS), resulting in molecular and cellular dysfunction. ${ }^{1}$ ROS can damage virtually any biological molecule in its vicinity including; DNA, essential proteins, and membrane lipids. ${ }^{2}$ Parkinson's disease is a neurodegenerative disease characterized by the selective loss of dopamine neurons of the substantia nigra pars compacta. The events, which trigger and/or mediate the loss of nigral dopamine neurons, remains unclear. Neuroleptic-induced catalepsy has long been used as an animal model for screening drugs for parkinsonism. ${ }^{3}$ Catalepsy is defined as the failure to correct an externally imposed posture. A condition characterized by inactivity, decreased responsiveness to stimuli, and a tendency to maintain an immobile posture. The limbs tend to remain in whatever position they are placed (waxy flexibility). Catalepsy may be associated with psychotic disorders (eg, schizophrenia, catatonia), nervous system drug toxicity, and other conditions. The catalepsy test is widely used to evaluate motor effects of drugs that act on the extrapyramidal system. ${ }^{4}$ Evidence suggests that immense oxidative stress, free radical formation, ${ }^{5}$ genetic susceptibility, ${ }^{6}$ and programmed cell death $^{7}$ are the main causes for neurodegeneration associated with Parkinson's and other
Correspondence: Mohammed Ibrahim Nizam Institute of Pharmacy and Research Center, Deshmukhi,

Pochampally (M), Near Ramoji Film City, Nalgonda, (AP), India

$\mathrm{Tel}+9 \mid 8685202$ I35

Fax +91 4023240575

Email ibrahim_cce@rediffmail.com 
related diseases. The neuropathology of the disease is based on depigmentation and cell loss in the dopaminergic nigrostraital tract of the brain, with the corresponding decrease in the striatal dopamine (DA) concentration. ${ }^{8}$ Besides, dopamine receptor blockade and catecholamine depletion, other neurochemical hypotheses have been proposed for the development of catalepsy such as striatonigral GABAergic (gamma-aminobutyric acid), cholinergic, glutamate, and serotonoergic. ${ }^{9-11}$ Haloperidol is an antipsychotic drug which is used in the treatment of schizophrenia and other affective disorders. It blocks dopaminergic action in the nigrostraital pathway leading to a high frequency of extrapyramidal motor side effects. ${ }^{12}$ In animal models, haloperidol induces a behavioral state known as catalepsy in which the animals are unable to correct externally imposed postures. ${ }^{13}$ The use of haloperidol has been associated with an increased level of oxidative stress in the brain. ${ }^{14}$ This evidence suggests a possible role for antioxidants in the treatment of haloperidol-induced catalepsy. The brain is made up of $70 \%$ lipid and any kind of stress is usually manifested by lipid peroxidative damage. ${ }^{15}$ The extent of this damage can be used to evaluate the degree of cellular harm. Stress-induced lipid peroxidative damage in the brain can be quantified by either determining the amount of peroxidative products or the rates of enzyme-catalyzed reactions neutralizing free radical intermediates such as superoxide dismutase (SOD). SOD is a primary, natural, and free radical scavenging and antioxidant enzyme in the body. The estimation of the activity of such antioxidant enzymes such as SOD, catalase, or glutathione peroxidase, can be used to assess the therapeutic effects of different antioxidant agents. ${ }^{16}$

Nardostachys jatamansi (N. jatamansi) (Valirenaceae) is indigenous to the Himalayan regions of India. In Ayurveda, roots and rhizomes of $N$. jatamansi are used to treat hysteria, epilepsy, and convulsions. ${ }^{17}$ The decoction of the drug is also used in neurological disorders, insomnia and disorders of cardiovascular system. ${ }^{18}$ The sesquiterpenes (Jatamansic acid, Jatamansone), lignans and neolignans are reported to be present in the roots of this plant. ${ }^{19,20}$ Rhizomes are reported to contain a terpenoid ester, Nardostachysin I. ${ }^{21}$ To date much research has been undertaken to evaluate the drug to treat various neurological and cardiovascular disorders in various animal models and is widely used in ayurvedic formulations. It is reported to possess antidepressant activity, ${ }^{22}$ anticonvulsant activity, ${ }^{23}$ antiarrhythmic activity, ${ }^{24}$ and possess antioxidant, and lipid peroxidation activity in doxorubicin-induced cardiac damage in rats. ${ }^{25}$ It is also reported to improve learning and memory in mice ${ }^{26}$ and to enhance biogenic amine activity. ${ }^{27}$ An acetone extract of $N$. jatamansi has shown significant inhibition of benzoyl peroxide-induced cutaneous oxidative stress, toxicity, and ear edema in mice. ${ }^{28}$ It has also been reported to possess protective activity in 6-hydroxydopamine-induced, parkinsonism in rats. ${ }^{29}$ These pharmacological properties of $N$. jatamansi prompted us to evaluate its efficacy in haloperidol-induced parkinsonism.

\section{Materials and methods}

\section{Plant material}

Dried roots of $N$. jatamansi were purchased from a herbal market (Chennai, Tamil Nadu, India) and authenticated by Dr P Jayaraman, Director of the Plant Anatomy Research Centre, Chennai, India. A specimen voucher was deposited at the department of Pharmacology, C L Baid Metha College of Pharmacy, Chennai, India.

\section{Preparation of aqueous extract of $N$. jatamansi}

The dried roots were coarsely powdered and extracted with distilled water for 48 hours by cold maceration at room temperature before being filtered. The filtrate was concentrated in rotary vacuum evaporator. Percentage yield was calculated with respect to the dried material and screened for its phytoconstituents. The extract obtained was suspended in $1 \% \mathrm{v} / \mathrm{v}$ Tween 80 for oral administration.

\section{HPTLC profile}

Chromatography was performed on high performance thin layer chromatography (HPTLC) plates coated with $0.25 \mathrm{~mm}$ layer of silica gel 60 F254 (Merck, München, Germany). Before using, the plates were washed with methanol and activated at $110^{\circ} \mathrm{C}$ for 5 minutes Samples were applied as $4 \mathrm{~mm}$ wide bands and $6 \mathrm{~mm}$ apart by using a Linomat IV sample applicator (Camag Muttenz, Basel, Switzerland) equipped with $100 \mu \mathrm{L}$ syringe. A constant application rate of $5 \mu \mathrm{L} /$ second was used. The mobile phase was petroleum ether-acetone $(3: 1 \mathrm{v} / \mathrm{v})$ and chromatograms were monitored at $254 \mathrm{~nm}$ (Figure 1).

\section{Experimental animals}

Inbred adult Wistar rats of either sex, weighing 150-200 gm were obtained from the animal house of the C L Baid Metha College of Pharmacy, India. The animals were maintained in a well-ventilated room with a 12-hour light/dark cycle in standard polypropylene cages under controled temperature $\left(26 \pm 1^{\circ} \mathrm{C}\right)$ and humidity $(30 \%-40 \%)$. They were fed with a standard pellet diet obtained from Poultry Research Station, Nandanam, Chennai, India. Water was supplied to the 


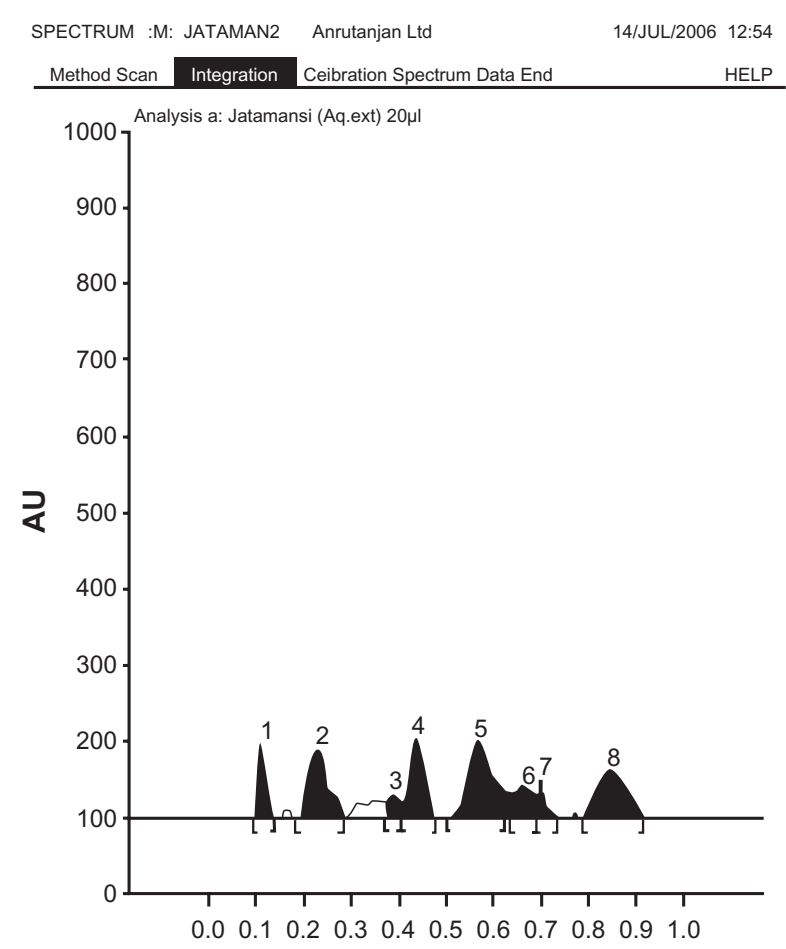

[Rf]

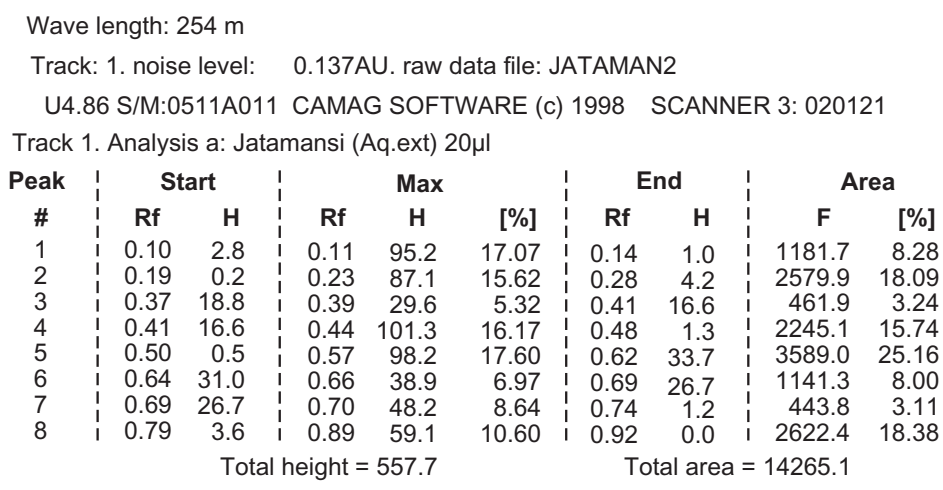

Figure I HPTLC chromatogram of aqueous extract of $N$. jatamansi.

Abbreviation: HPTLC, high performance thin layer chromatography.

animals ad libitum. Experimental protocols were approved by Institutional Animal Ethics Committee (IAEC) of C.P.C.S.E.A with ref no. IAEC/08/14/CLBMCP/2005-2006, dated 12-20-2005.

\section{Toxicity studies}

\section{Acute toxicity studies}

Rats selected by a random sampling technique were used in the study. Acute oral toxicity was performed as per Organization for Economic Co-operation and Development (OECD)423 guidelines. ${ }^{30}$ Three male Wistar rats weighing between 150-200 g were used for each dose. The dose levels of $5 \mathrm{mg}$, $50 \mathrm{mg}, 500 \mathrm{mg}, 1000 \mathrm{mg}, 2000 \mathrm{mg}$, and $5000 \mathrm{mg} / \mathrm{kg} /$ body weight, per os were selected. The lethal dose (LD)-50 value of the extract was determined. The drug was administered orally to rats, which were fasted overnight with water ad libitum before the administration of the drug. The body weight of the rat was noted before and after treatment. The animals were observed for toxic symptoms, such behavioral changes, locomotion, convulsions, and mortality for 72 hours.

\section{Repeated oral toxicity studies}

In repeated oral toxicity studies drug extracts are administered to the animal for a period covering approximately $10 \%$ of the expected life of the animal. Usually, the dose levels are lower than for acute studies and allow chemicals to accumulate in the body before lethality occurs, if the chemical possesses this ability. ${ }^{31}$ Wistar rats of both sexes, $150-200 \mathrm{~g}$ 


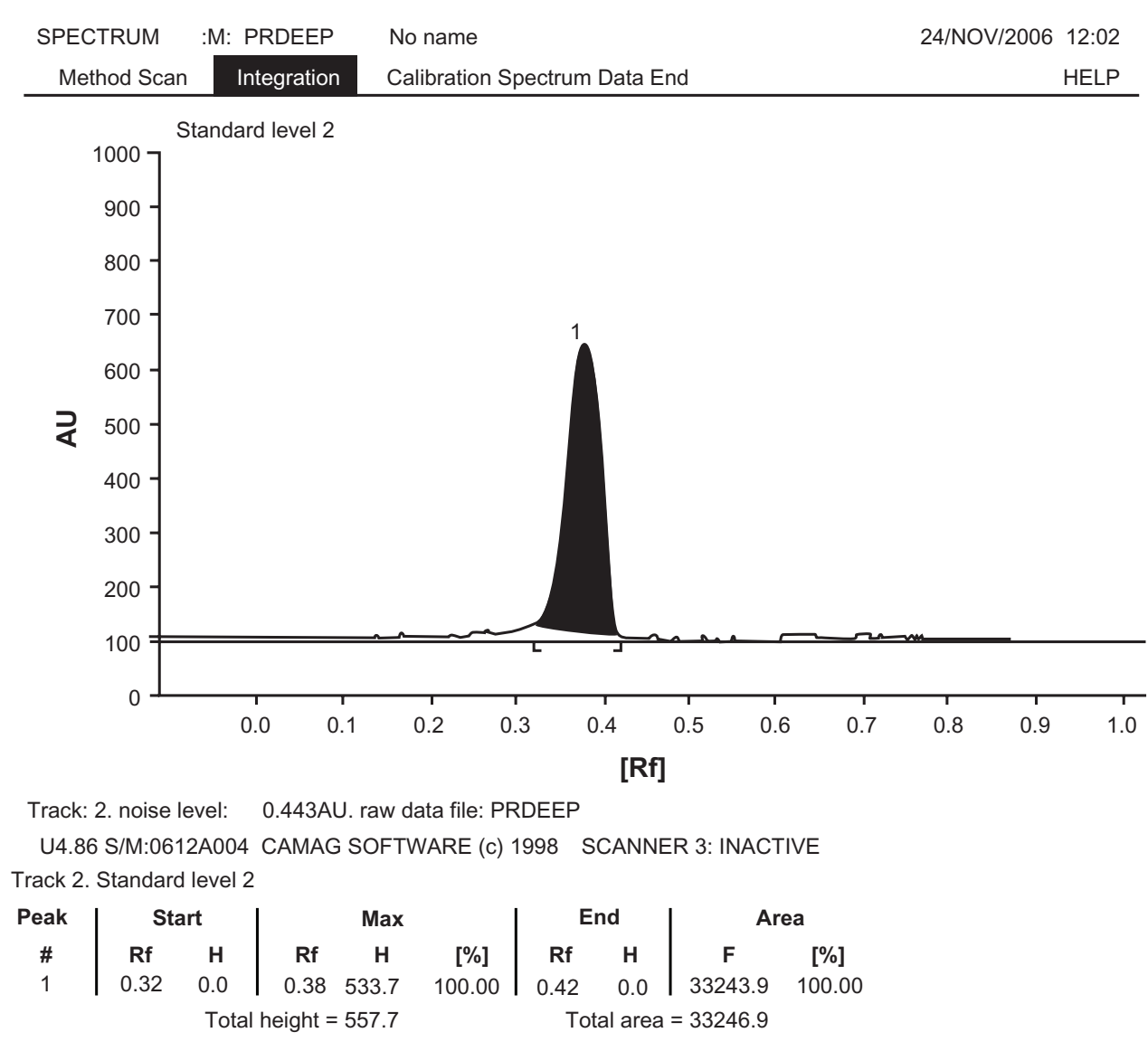

Figure 2 HPTLC chromatogram of standard (Reference compound) Jatamansone. Abbreviation: HPTLC, high performance thin layer chromatography.

were used for the study and kept in a temperature-controlled environment $\left(26^{\circ} \mathrm{C} \pm 1{ }^{\circ} \mathrm{C}\right)$ with a 12 -hour light/dark cycle. Food and water were freely available and were recorded each at 3-day intervals. The animals were divided into one control group and one treated group, each group consisting of six animals. The control group received Tween 80 and each treated group received the aqueous extract $(1000 \mathrm{mg} / \mathrm{kg}$ body weight), by gavage once a day for 28 days. The animals were each weighed every 3 days. At the end of the experiment, blood was collected from the orbital sinus, under ether anesthesia, for biochemical and hematological analysis. After the blood collection, the animals were sacrificed by cervical displacement and selected organs (brain, lungs, liver, heart, pancreas, kidney, and testis) were removed and collected in $10 \%$ formalin solution in readiness for preparation of sections. The histopathological studies were carried following the method of Mukherjee. ${ }^{32}$

\section{Experimental design}

Adult male Wistar rats (180-250 g) were divided into six groups each containing six animals. Group I received the vehicle 1\% Tween 80 solution and served as the control. Group II received haloperidol alone and served as the cataleptic control without any drug treatment. Group III received a combination of L-dopa and carbidopa (100 mg $+25 \mathrm{mg} / \mathrm{kg}$ by intraperitoneal administration) and served as positive control. Groups IV, V, and VI received $N$. jatamansi at a dose of $100,250,500 \mathrm{mg} / \mathrm{kg}$ body weight, respectively. Thirty minutes after the administration of these drugs, catalepsy was induced by the intraperitonial administration of haloperidol at a dose of $1 \mathrm{mg} / \mathrm{kg}$ body weight in normal saline. This procedure was repeated for 15 days. All the behavioral studies were performed at room temperature in a calm room without any external interference. The severity of catalepsy was measured every 30 minutes thereafter for a total duration for 3 hours. Catalepsy of an individual rat was measured in a stepwise manner using a scoring method described below. After 15 days of behavioral studies, animals were sacrificed by cervical dislocation and the whole brain was immediately dissected out and washed in ice-cold saline to remove all traces of blood. The brains were weighed and a $10 \%$ tissue homogenate was prepared in $0.025 \mathrm{M}$ Tris- $\mathrm{HCl}$ buffer at $\mathrm{pH} 7.5$ and used to measure the activities of thiobarbituric acid reactive substances (TBARS). Enzyme activity was assayed in 10\% brain homogenates prepared in $0.2 \mathrm{M}$ phosphate buffer, $\mathrm{pH}$ 8.0. 
Table I Acute toxicity study

\begin{tabular}{|c|c|c|c|c|c|c|}
\hline \multirow[t]{2}{*}{ Drug treatment } & \multirow[t]{2}{*}{ Dose } & \multicolumn{2}{|c|}{ Average body weight of the animal in grams } & \multirow[t]{2}{*}{ Signs of toxicity } & \multirow[t]{2}{*}{ Effect observed } & \multirow[t]{2}{*}{ Death } \\
\hline & & $\begin{array}{l}\text { Before treatment } \\
\text { (Ist day) }\end{array}$ & $\begin{array}{l}\text { After treatment } \\
\text { (14th day) }\end{array}$ & & & \\
\hline $\begin{array}{l}\text { Aqueous extract } \\
\text { of } N \text {. jatamansi }\end{array}$ & $5 \mathrm{mg} / \mathrm{kg}$ & 169 & 175 & $\begin{array}{l}\text { No signs } \\
\text { of toxicity }\end{array}$ & No effect & Nil \\
\hline $\begin{array}{l}\text { Aqueous extract } \\
\text { of } N \text {. jatamansi }\end{array}$ & $50 \mathrm{mg} / \mathrm{kg}$ & 160 & 169 & $\begin{array}{l}\text { No signs } \\
\text { of toxicity }\end{array}$ & No effect & Nil \\
\hline $\begin{array}{l}\text { Aqueous extract } \\
\text { of } N \text {. jatamansi }\end{array}$ & $500 \mathrm{mg} / \mathrm{kg}$ & 167 & 174 & $\begin{array}{l}\text { No signs } \\
\text { of toxicity }\end{array}$ & No effect & Nil \\
\hline $\begin{array}{l}\text { Aqueous extract } \\
\text { of } N \text {. jatamansi }\end{array}$ & $1000 \mathrm{mg} / \mathrm{kg}$ & 173 & 179 & $\begin{array}{l}\text { No signs } \\
\text { of toxicity }\end{array}$ & No effect & Nil \\
\hline $\begin{array}{l}\text { Aqueous extract } \\
\text { of } N \text {. jatamansi }\end{array}$ & $2000 \mathrm{mg} / \mathrm{kg}$ & 155 & 164 & $\begin{array}{l}\text { No signs } \\
\text { of toxicity }\end{array}$ & No effect & Nil \\
\hline $\begin{array}{l}\text { Aqueous extract } \\
\text { of } N \text {. jatamansi }\end{array}$ & $5000 \mathrm{mg} / \mathrm{kg}$ & 182 & 195 & $\begin{array}{l}\text { No signs } \\
\text { of toxicity }\end{array}$ & No effect & Nil \\
\hline
\end{tabular}

Notes: Body weight and signs of toxicity observed following treatment of aqueous extract of N. Jatamansi in rats for 14 days.

\section{Behavioral studies}

\section{Measurement of catalepsy by block method ${ }^{33}$}

This scoring method followed is in three steps. Step 1: The rat was taken out of the home cage and placed on a table. If the rat failed to move when touched or pushed gently on the back a score of 0.5 was assigned. Step II: The front paws of the rats were placed alternately on a $3-\mathrm{cm}$ high block. If the rat failed to correct the posture within 15 seconds, a score of 0.5 for each paw was added to the score of step 1. Step III: The front paws of the rat were placed alternately on a 9-cm high block, if the rat failed to correct the posture within 15 seconds a score of 1 for each paw was added to the scores of steps I and II. Thus, the highest score for any animal was 3.5 (cut off score) and that reflects total catalepsy (Table 3).

\section{Behavioral assessment by metal bar test}

Behavioral assessment in haloperidol-induced cataleptic rats was studied by the method of Kulkarni. ${ }^{34}$ Cataleptic behavior was measured with a high bar test method. Catalepsy score was measured for 4 hours at one-hour intervals after haloperidol administration by gently placing both forepaws of the rat over a metal bar (diameter 2-5 mm suspended 6 $\mathrm{cm}$ above the table top). The intensity of catalepsy assessed by counting the time in seconds until the rat brought both forepaws down to the tabletop, with a maximum cutoff time of 3 minutes. Finally, scores at different time points $(0,60,120,180$ and 240 minutes after haloperidol injection) were added and expressed as a cumulative catalepsy score for comparison purposes (Table 4).

\section{Biochemical studies Estimation of lipid peroxidation products}

Lipid peroxidation was estimated colorimetrically in brain tissue by quantifying TBARS according to the method of Niehaus and Samuelson. ${ }^{35}$ In brief; for the estimation of TBARS the supernatant of the tissue homogenate was treated with tertiary butanol-trichloroacetic acid-hydrochloric acid, (TBA-TCA- $\mathrm{HCl}$ ) reagent and mixed thoroughly. The mixture was kept in boiling water bath for 15 minutes. After cooling, the tubes were centrifuged for 10 minutes and the supernatant

Table 2 Repeated oral toxicity studies

\begin{tabular}{|c|c|c|c|c|c|c|c|}
\hline \multirow[t]{2}{*}{ Groups } & \multirow[t]{2}{*}{ Hb (gm \%) } & \multirow{2}{*}{$\begin{array}{l}\text { RBC } \\
\text { (millions } / \mathrm{mm}^{2} \text { ) }\end{array}$} & \multirow{2}{*}{$\begin{array}{l}\text { WBC } \\
\left(\text { per } \mathrm{mm}^{2}\right)\end{array}$} & \multicolumn{4}{|c|}{ Differential count } \\
\hline & & & & $\begin{array}{l}\text { Neutrophils } \\
\text { (\%) }\end{array}$ & $\begin{array}{l}\text { Lymphocytes } \\
\text { (\%) }\end{array}$ & $\begin{array}{l}\text { Monocytes } \\
\text { (\%) }\end{array}$ & $\begin{array}{l}\text { Eosinophils } \\
\text { (\%) }\end{array}$ \\
\hline Control & $\begin{array}{l}14.62 \pm \\
0.06256 \mathrm{~ns}\end{array}$ & $\begin{array}{l}5.297 \pm \\
0.16222 \mathrm{~ns}\end{array}$ & $\begin{array}{l}7487 \pm \\
274.08 \mathrm{~ns}\end{array}$ & $\begin{array}{l}50.33 \pm \\
1.406 \mathrm{~ns}\end{array}$ & $\begin{array}{l}45.17 \pm \\
0.8333 \mathrm{~ns}\end{array}$ & $\begin{array}{l}2.333 \pm \\
0.6148 \mathrm{~ns}\end{array}$ & $\begin{array}{l}2.167 \pm \\
05426 \mathrm{~ns}\end{array}$ \\
\hline Test & $\begin{array}{l}14.63 \pm \\
0.08028 n s\end{array}$ & $\begin{array}{l}5.075 \pm \\
0.1420 \mathrm{~ns}\end{array}$ & $\begin{array}{l}7710 \pm \\
246.8 \mathrm{~ns}\end{array}$ & $\begin{array}{l}52.17 \pm \\
1.167 \mathrm{~ns}\end{array}$ & $\begin{array}{l}41.83 \pm \\
1.447 \mathrm{~ns}\end{array}$ & $\begin{array}{l}2.667 \pm \\
0.6146 \mathrm{~ns}\end{array}$ & $\begin{array}{l}3.500 \pm \\
0.6708 \mathrm{~ns}\end{array}$ \\
\hline
\end{tabular}

Notes: Values are expressed in mean \pm SEM. Each group consists of 6 rats. Statistical significance test for comparison was done by Student's $t$-test. Abbreviations: $\mathrm{ns}$, not significant; $\mathrm{Hb}$, hemoglobin;WBC, white blood corpuscles; RBC, red blood corpuscles. 
Table 3 Effect of aqueous extract of $N$. jatamansi on haloperidol-induced catalepsy by block method

\begin{tabular}{|c|c|c|c|c|c|c|}
\hline Drug treatment & $30 \mathrm{~min}$ & $60 \mathrm{~min}$ & $90 \mathrm{~min}$ & $120 \mathrm{~min}$ & $150 \mathrm{~min}$ & $180 \mathrm{~min}$ \\
\hline Tween 80 & $0.0 \pm 0.0$ & $0.0 \pm 0.0$ & $0.0 \pm 0.0$ & $0.0 \pm 0.0$ & $0.0 \pm 0.0$ & $0.0 \pm 0.0$ \\
\hline Haloperidol & $2.00 \pm 0.224^{*}$ & $2.833 \pm 0.21 \mathrm{la}{ }^{* *}$ & $3.5 \pm 0.0 \mathrm{a} * *$ & $3.5 \pm 0.0 \mathrm{a} * *$ & $3.167 \pm 0.21 \mathrm{Ia} * *$ & $3.333 \pm 0.167 \mathrm{a}^{* *}$ \\
\hline $\begin{array}{l}\text { N. jatamansi }(100 \mathrm{mg})+ \\
\text { haloperidol }\end{array}$ & $1.85 \pm 0.457^{*}$ & $2.792 \pm 0.322 *$ & $2.612 \pm 0.563^{*}$ & $2.356 \pm 0.043 b^{*}$ & $2.114 \pm 0.63 b^{*}$ & $1.923 \pm 0.673 \mathrm{~b} * *$ \\
\hline $\begin{array}{l}\text { N. jatamansi }(250 \mathrm{mg})+ \\
\text { haloperidol }\end{array}$ & $1.500 \pm 0.342 *$ & $2.500 \pm 0.259 *$ & $2.167 \pm 0.211 *$ & $1.833 \pm 0.21 \mathrm{I} \mathrm{b}^{* *}$ & $1.4 I 7 \pm 0.0833 b^{* *}$ & $1.02 \pm 0.823 \mathrm{~b} * *$ \\
\hline $\begin{array}{l}\text { N. jatamansi }(500 \mathrm{mg})+ \\
\text { haloperidol }\end{array}$ & $1.00 \pm 0.213^{*}$ & $2.080 \pm 0.326^{*}$ & $1.526 \pm 0.243^{* *}$ & $1.287 \pm 0.0833 b^{* *}$ & $1.236 \pm 0.056 \mathrm{~b} * *$ & $0.5000 \pm 0.224 b * *$ \\
\hline $\begin{array}{l}\text { L-dopa and carbidopa }+ \\
\text { haloperidol }\end{array}$ & $0.5833 \pm 0.833^{*}$ & $1.667 \pm 0.117^{* *}$ & $1.333 \pm 0.105^{* *}$ & $1.250 \pm 0.112 b^{* *}$ & $1.13 \pm 0.042 b * *$ & $0.5 \pm 0.0 \mathrm{~b} * *$ \\
\hline
\end{tabular}

Notes: Values are mean \pm SEM $(n=6)$. Statistical analysis by one-way ANOVA, followed by Dunnett's multiple comparison test.

$* P<0.05$, **P $<0.0$ I.

Abbreviations: SEM, standard error of mean; Min, minutes.

taken for measurement. The developed color was read at $535 \mathrm{~nm}$ using a UV spectrophotometer (Hitachi 912) against a reagent blank and expressed as $\mathrm{mM}$ per $100 \mathrm{~g}$ tissue.

\section{Estimation of antioxidants}

Catalase (CAT) was assayed colorimetrically at $620 \mathrm{~nm}$ and was expressed as micromoles of $\mathrm{H}_{2} \mathrm{O}_{2}$ consumed per minute per mg of protein; using the method described by Sinha. ${ }^{36}$ The reaction mixture $(1.5 \mathrm{~mL}$, volume) contained $1.0 \mathrm{~mL}$ of $0.01 \mathrm{M} \mathrm{pH} 7$ phosphate buffer, $0.1 \mathrm{~mL}$ of tissue homogenate and $0.4 \mathrm{~mL}$ of $2 \mathrm{M} \mathrm{H}_{2} \mathrm{O}_{2}$. The reaction was stopped by the addition of $2 \mathrm{~mL}$ of dichromate-acetic acid reagent (5\% potassium dichromate and glacial acetic acid mixed in the ratio of 1:3). The assay for SOD was based on SOD mediated inhibition of the reduction of nitroblue tetrazolium to blue formazan by superoxide anions as described by Beauchamp and Fridovich. ${ }^{37}$ The total protein present in the homogenate was estimated following the method described by Lowry. ${ }^{38}$ Units of SOD activity determined were expressed in terms of milligrams of total protein (TP). Reduced glutathione (GSH) was determined by the method of Ellman. ${ }^{39}$ One $\mathrm{mL}$ of supernatant was treated with $0.5 \mathrm{~mL}$ of Ellman's reagent and $3 \mathrm{~mL}$ of phosphate buffer $(0.2 \mathrm{M}, \mathrm{pH} 8.0)$. The absorbance was read at $412 \mathrm{~nm}$. The activity of GSH was expressed as nM GSH formed/g tissue.

\section{Statistical analysis}

Each group of rats assigned to a specific drug treatment each group consisted of 6-9 animals. All the values are expressed as mean \pm standard error of mean (SEM). The data were analyzed by analysis of variance (anova) followed by Tukey test. The criterion for statistical significance was $P<0.05$.

\section{Results}

The phytochemical analysis of an aqueous root extract of N. Jatamansi revealed the presence of sterols, carbohydrates, terpenes, phenols, gums and mucilage. The HPTLC fingerprint of the aqueous extract showed the presence of eight spots $\left(\mathrm{R}_{\mathrm{f}}\right.$ values $0.11,0.23,0.39,0.44,0.57,0.66,0.70$ and 0.84 ) (Figure 1) at a wavelength of $254 \mathrm{~nm}$. The standard

Table 4 Effect of aqueous extract of $N$. jatamansi on Haloperidol induced catalepsy by metal bar test

\begin{tabular}{|c|c|c|c|c|c|}
\hline Drug treatment & $0 \mathrm{~min}$ & $60 \mathrm{~min}$ & $120 \mathrm{~min}$ & $180 \mathrm{~min}$ & $240 \mathrm{~min}$ \\
\hline Tween 20 & $8.500 \pm 1.088$ & $7.167 \pm 1.138$ & $5.167 \pm 0.792$ & $5.667 \pm 0.558$ & $5.667 \pm 0.955$ \\
\hline Haloperidol treated & $5.833 \pm 0.872$ & $138.3 \pm 3.333^{* *}$ & $165 \pm\left. 3.65\right|^{* *}$ & $165.0 \pm 5.625^{* *}$ & $161.7 \pm 5.270^{* *}$ \\
\hline N. jatamansi (100 mg) + Haloperidol & $6.832 \pm 0.056$ & $102 \pm 2.348^{*}$ & $94.5 \pm 4.387^{*}$ & $72.3 \pm 2.567^{*}$ & $51.2 \pm 3.246^{*}$ \\
\hline N. jatamansi (250 mg) + Haloperidol & $8.167 \pm 0.654$ & $65.00 \pm 4.830 * *$ & $58.83 \pm 3.468 * *$ & $48.00 \pm 3.109 * *$ & $23.33 \pm 2.472^{* *}$ \\
\hline N. jatamansi (500 mg) + Haloperidol & $5.643 \pm 0.423$ & $43.42 \pm 3.147 * *$ & $36.23 \pm 4.123 * *$ & $28.3 \pm 2.148^{* *}$ & $18.24 \pm 0.185^{* *}$ \\
\hline L-Dopa and carbidopa + Haloperidol & $7.500 \pm 0.8851$ & $32.50 \pm 3.354^{* *}$ & $27.50 \pm\left. 2.14\right|^{* *}$ & $23.00 \pm 1.826^{* *}$ & $15.00 \pm 1.826 * *$ \\
\hline
\end{tabular}

Notes: Values are mean \pm SEM $(n=6)$. Statistical analysis by one-way ANOVA, followed by Dunnett's multiple comparision test. $* P<0.05$, $* * P<0.01$.

Abbreviations: SEM, standard error of mean; Min, minutes. 
reference compound, Jatamansone, had the $\mathrm{R}_{\mathrm{f}}$ value of 0.39 (Figure 2), hence it is confirmed that the aqueous extract contains terpenoids. The acute oral toxicity was undertaken according to the OECD guidelines 423 (acute toxicity class method). There was no considerable change in body weight either before or after experimental treatment and no signs of toxicity were observed (Table 1). The LD50 test of the aqueous extract was found to be greater than $5000 \mathrm{mg} / \mathrm{kg}$ body weight after oral administration. Repeated oral toxicity was carried out by administration of the extract at a dose of $1000 \mathrm{mg} / \mathrm{kg}$ body weight per os for 28 days. The extract treated rats did not show any significant changes in hematological parameters (hemoglobin red blood corpuscles $[\mathrm{RBC}]$, white blood corpuscles [WBC], neutrophils, monocytes, eosinophils and lymphocytes) when compared with the normal control animals (Table 2). Histopathological examinations of the internal organs, ie, liver, kidney and brain, did not shown any changes in their normal architecture, suggesting the safety of the drug (Figure 3 ) as the oral administration of the drug to normal rats had no significant effect. Based on these findings a dose of 100, 250, and $500 \mathrm{mg} / \mathrm{kg}$ bodyweight were selected for the study. The cataleptic scores of the present study are given in Table 3 and 4 , assessed by block method and metal bar test, respectively. Haloperidol induced catalepsy significantly $(P<0.01)$ at a dose of $1 \mathrm{mg} / \mathrm{kg}$ (intraperitoneal administration). Significant reversal in haloperidol-induced catalepsy was observed with the administration of $N$. jatamansi aqueous extract and combination of L-dopa and carbidopa. The maximal decrease $(P<0.01)$ in catalepsy was observed in the group receiving aqueous extract of $N$. Jatamansi at a dose of $250 \mathrm{mg} / \mathrm{kg}$. However, there was no pronounced reduction in the cataleptic scores at a dose of $500 \mathrm{mg} / \mathrm{kg}$, but almost similar results were observed as observed at a dose of $250 \mathrm{mg} / \mathrm{kg}$ body weight.

The levels of lipid peroxidation products and antioxidants in the brains of haloperidol, drug-treated and control groups are shown in Table 5. The haloperidol-treated rats showed a significant increase $(P<0.01)$ in TBARS and there was also a significant reduction $(P<0.01)$ in SOD, CAT, and GSH in the brain tissue. Oral administration of the extract

\section{Control}

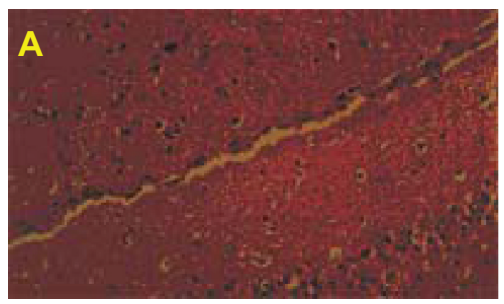

Brain

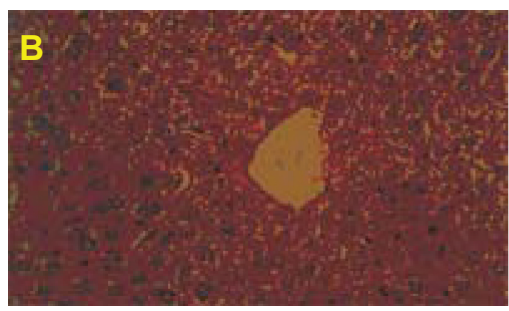

Liver

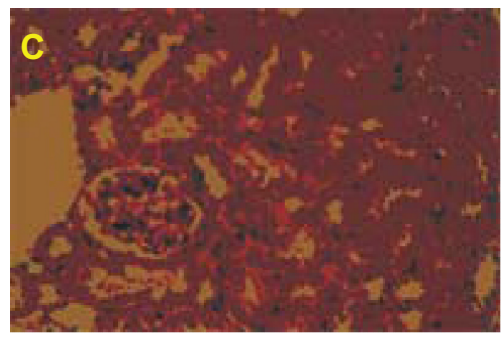

Kidney
Test

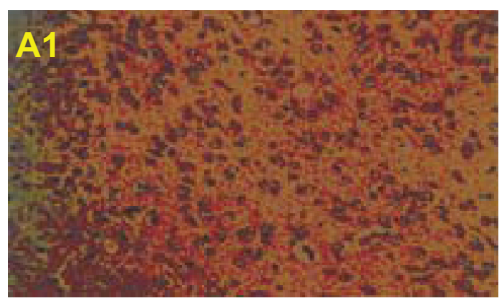

Brain

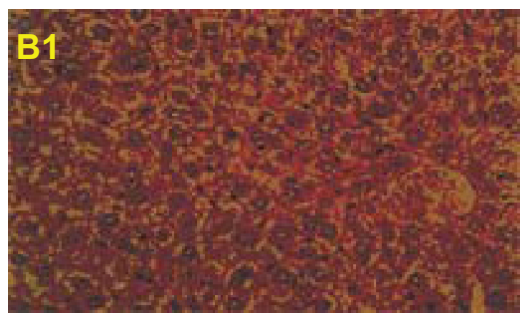

Liver

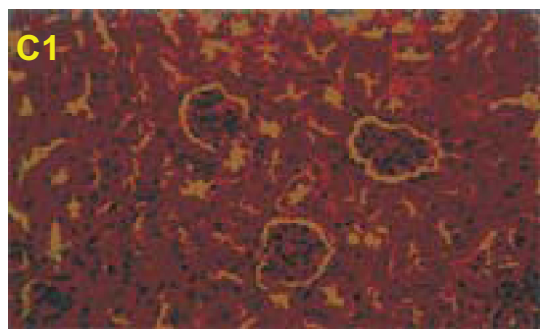

Kidney

Figure 3 Histopathological slides of Brain (A control, A I test), Liver (B control, BI test) and Kidney (C control, Cl test), Repeated oral toxicity study of Nardostachys jatamansi treatment for 28 days in rats showed no pathological changes. 
Table 5 Effect of N. jatamansi on TBARS, SOD, CAT, and GSH levels in normal and catalepsy-induced rat brain

\begin{tabular}{|c|c|c|c|c|}
\hline Group & TBARS (mM/l $00 \mathrm{~g}$ tissue) & SOD $\left(U^{A}\right)$ & 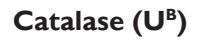 & GSH (mg// $00 \mathrm{~g}$ tissue $)$ \\
\hline Control & $1.13 \pm 0.08$ & $7.83 \pm 0.70$ & $2.99 \pm 0.27$ & $11.53 \pm 0.50$ \\
\hline Haloperidol treated & $1.99 \pm 0.12^{* * *}$ & $4.58 \pm 0.31 * * *$ & $0.75 \pm 0.05^{* * *}$ & $5.82 \pm 0.33^{* * *}$ \\
\hline L-dopa and carbidopa + Haloperidol & $1.22 \pm 0.05 * * *$ & $6.42 \pm 0.28 * * *$ & $2.19 \pm 0.22^{* * *}$ & $9.15 \pm 0.28^{* * *}$ \\
\hline N. jatamansi (100 mg) + Haloperidol & $|3| \pm 0.43^{*}$ & $5.78 \pm 0.45^{* *}$ & $1.95 \pm 0.20 *$ & $8.48 \pm 0.5 I^{*}$ \\
\hline N. jatamansi (250 mg) + Haloperidol & $1.15 \pm 0.06 * * *$ & $6.81 \pm 0.50^{* * *}$ & $2.49 \pm 0.29 * *$ & $9.98 \pm 0.46 * * *$ \\
\hline N. jatamansi $(500 \mathrm{mg})+$ Haloperidol & $1.18 \pm 0.21^{* * *}$ & $6.89 \pm 0.38^{* * *}$ & $2.43 \pm 0.23 * *$ & $9.94 \pm 0.38^{* * *}$ \\
\hline
\end{tabular}

Notes: Values are mean \pm SEM of six samples of six observations. Statistical significant test for comparison was done by ANOVA, followed Dunnett's test. ${ }^{A} A m o u n t$ of enzyme required to inhibit $50 \%$ of NBT reduction per mg protein. ${ }^{B}$ Micromoles of $\mathrm{H}_{2} \mathrm{O}_{2}$ consumed per min per mg protein.

Abbreviations: SEM, standard error of mean;TBARS, thiobarbituric acid reactive substances; GSH, reduced glutathione; CAT, catalase; SOD, superoxide dismutase.

along with haloperidol administration significantly restored $(P<0.01)$ the peroxides and antioxidant levels to near normal in the brains of the test animals. For all the parameters studied, $N$. jatamansi extract administered at doses of 250 and $500 \mathrm{mg} / \mathrm{kg}$ bodyweight showed significant effects. L-dopa and carbidopa also showed a significant effect in all the parameters studied in rats.

\section{Discussion}

The central nervous system is especially vulnerable to free radical damage because of the brain's high oxygen consumption, its abundant lipid content, and the relative paucity of antioxidant enzymes as compared with other tissues. ${ }^{40}$ Evidence also indicates that ROS may stimulate extracellular release of excitatory amino acids ${ }^{41}$ Glutamate is the major excitatory amino acid in the brain which acts through various types of ionotropic receptors, the most significant being $N$-methyl $D$-aspartate (NMDA) receptors. There seems to be a bidirectional relationship between the ROS production and the release of excitatory aminoacids. ${ }^{42}$ Free radicals generated in the brain are also reported to influence gene expression, subsequently effecting apoptosis and neuronal death. ${ }^{43}$ In the brain, an array of cellular defense systems exists to counterbalance the ROS. These include enzymatic and nonenzymatic antioxidants that lower the concentration of free radical species and repair oxidative cellular damage. The brain is known to synthesize molecules like glutathione and NADPH. Glutathione functions as a major antioxidant in tissue defense against free radicals in the brain. However, the concentration of glutathione is, relatively, in lesser quantities in the brain as compared to the other organs of the body. ${ }^{40}$ The natural antioxidant system present in brain can be in form of enzymes like catalase, peroxidase, superoxide dismutase or low molecular weight antioxidants (ascorbic and lipoic acids, carotenoids or indirectly acting chelating agents). ${ }^{43}$ Free radical scavengers or antioxidants function as biological bodyguards for essential molecules by either neutralizing reactive species before they mutilate a molecule or they repair damage that has been inflicted.

The present study demonstrates the antioxidant effects of an aqueous root extract of $N$. Jatamansi in haloperidol-induced, cataleptic oxidative stress in rats. The induction of free radicals in mammals by haloperidol is well established. Previous studies have shown that dopamine receptors in the striatum are involved in neuroleptic-induced catalepsy. It has been demonstrated that the cataleptic effects of haloperidol are apparently mediated by dopamine receptors localized postsynaptically on strial neurons..$^{13}$ It is also well established that the administration of haloperidol leads to an increase in the oxidative stress in the brain tissue. ${ }^{14}$ The increase in SOD observed in the present study supports the this concept. Superoxide formation is a major factor in oxygen toxicity and the superoxide dismutase enzyme constitutes an essential defense against it. Under normal conditions, decreased activity of antioxidant enzymes, such as SOD, glutathione peroxidase and catalase, in the brain leads to the accumulation of oxidative free radicals resulting in degenerative effects. ${ }^{44} \mathrm{An}$ increase in these enzymes under normal conditions would represent increased antioxidant activity and a protective mechanism in neuronal tissue, thus, constituting the first line of defense against oxidative stress in our body. However, in the presence of a free radical-quenching agent, the induction of the antioxidant enzymes is minimized. So, any overall decrease in cataleptic scores and SOD activity in the drug treated groups indicates the ability of the drug extract to combat oxidative stress in brain tissue and reduce the severity of haloperidol-induced catalepsy. The altered balance of the antioxidant enzymes caused by the decrease in CAT, SOD, GSH activities may be responsible for the inadequacy of the antioxidant defenses in 
combating ROS mediated damage. The decreased activities of CAT and SOD may be a response to increased production of $\mathrm{H}_{2} \mathrm{O}_{2}$ and $\mathrm{O}_{2}$ by the autooxidation. ${ }^{45}$ It has been suggested that these enzymes play an important role in maintaining physiological levels of oxygen and hydrogen peroxide by hastening the dismutation of oxygen radicals and eliminating organic peroxides and hydroperoxides. Treatment with $N$. jatamansi extract increased the activity of these enzymes by quenching the free radicals. Previously $N$. jatamansi has been reported to be a well known antioxidant and the ethanol extract of $N$. jatamansi is reported to possess potent antioxidant activity that scavenges free radicals generated after the induction of catalepsy. ${ }^{27}$ Significantly lower levels of lipid peroxides in the brains of the drug-treated group and increased activities of enzymatic and nonenzymatic antioxidants in the brain suggests that the extract reduces oxidative stress. In previous studies $N$. jatamansi has been reported to have antilipid peroxidative and protective effect in rat cerebral ischemia. ${ }^{46,47} N$. jatamansi has also been reported to enhance biogenic amine activity, ${ }^{48}$ decrease the level of dopamine and its metabolites and increasing the number of dopaminergic D2 receptors in striatum. ${ }^{29}$ Such evidence supports our study and indicates that the extract of $N$. jatamansi inhibits the symptoms of haloperidol-induced catalepsy in rats. The action by which the amelioration takes place may be attributed to one (or) more pharmacological/biochemical mechanisms. To conclude, the brain exhibits numerous morphological and functional alterations during oxidative stress, a factor implicated in the pathogenesis of many CNS disorders. Treatment of such neuronal disorders with $N$. jatamansi plant extract significantly decreases lipid peroxidation and significantly increases the antioxidants in the brain. The findings of this study suggest the possible antioxidant role of $N$. jatamansi in overcoming behavioral and neurochemical changes during oxidative stress. Since the catalepsy test has predictive value regarding extrapyramidal effects, the possibility of pharmacological interactions between haloperidol and $N$. jatamansi extract should be further investigated in clinical studies.

\section{Disclosures}

The authors report no conflicts of interest relevant to this research.

\section{References}

1. Gupta YK, Madhur Gupta, Kohli K. Neuroprotective role of melatonin in oxidative stress vulnerable brain. Indian J Physiol Pharmacol. 2003;47(4):373-386.

2. Wolff SP, Garner A, Dean RT. Free radicals lipids and protein degradation. Trends Biol Sci. 1986;11:27-31.
3. Anil kumar, Kulkarni SK. Effect of BR-16A(Mentat), a polyherbal formulation on drug induced catalepsy in mice. Indian J Exper Biol. 2006;44:45-48.

4. Sanberg PR, Bunsey MD, Giordano M. The catalepsy test: its up and downs. Behav Neurosci. 1988;102:748-759.

5. Jenner P. Oxidative stress and the pathogenesis of Parkinson's disease. Neurology. 1996;47:161-170.

6. Bandmann O, Marsden DC, Wood NW. Genetic aspects of Parkinson's disease. Mov Disord (Review). 1998;13:203-211.

7. Ziv I, Melamed E, Nardi N. Role of apoptosis in the pathogenesis of Parkinson's disease: a noval therapeutic opportunity. Mov Disord. 1998; 13:865-870.

8. Von Bohlen, Halbach O, Schober A, Krieglstein K. Genes, proteins, and neurotoxins involved in Parkinson's disease. Prog Neurobiol. 2004;73:151-177.

9. Bazian AS. Divergent and convergent mechanism of integrative activity of mammalian brain. Zh Vyssh Nerv Deiat Im I P Pavlova. 2001;51: 514-528.

10. Okuyama S. Atypical antipsychotic profile of sigma receptor ligands. Nippon Yakurigaku Zasshi. 1999;114:13-23.

11. Neal Belveau BS, Joyce JN, Lucki I. Serotonergic involvement in haloperidol-induced catalepsy. J Pharmacol Exp Ther. 1993; 265:207.

12. Farde L, Nordstrom AL, Wiesel FA, Pauli S, Halldin C, Sedvall G. Positron emission tomographic analysis of central D1 and D2 dopamine receptor occupancy in patients treated with classical neuroleptics and clozapine:Relation to extra-pyramidal side effects. Arch Gen Psychiatry. 1992;49:538-544.

13. Sanberg PR. Haloperidol-induced catalepsy is mediated by postsynaptic dopamine receptors. Nature. 1980;284:472-473.

14. Sagara Y. Induction of reactive oxygen species in neurons by haloperidol. Jour Neurochem. 1998;71:1002-1012.

15. Kedar NP. Can we prevent Parkinson's and Alzheimer's disease? J Postgrad Med. 2003;49:236-245.

16. Albina Arjuman, Vinod Nair, Gopalkrishna HN, Nandini M. Evaluation of the antioxidant potential of NR-ANX-C (a polyherbal formulation) and its individual constituents in reversing haloperidolinduced catalepsy in mice. Indian J Pharmacol. 2007;39(3): 151-154.

17. Bagchi A, Oshima Y, Hikino H. Neoligans and lignans of Nardostachys Jatamansi Roots. Planta Med. 1991;57:96-97.

18. Uniyal MR, Issar RK. Commercially and traditionally important medicinal plants of Mandakini valley of Uttarkhand Himalayas. J Res Indian Med. 1969;4(1):83-96.

19. Chatterji A, Prakashi SC. The treatise on Indian medicinal plants. National Institute of Science Communication. (Publication and Information Directorate), Volume. 5. New Delhi: 1997.

20. Arora RB. Nardostachys jatamansi, a chemical, pharmacological and clinical appraisal. New Delhi, India: Monograph Special Series, Indian Council of Medical Research; Volume 51. 1965.

21. Chatterjee A, Basak B, Saha M, et al. Structure and Stereo-chemistry of Nardostachysin, A New Terpenoid ester constituent of the Rhizomes of Nardostachys Jatamansi. J Nat Prod. 2000;63(11): 1531-1533.

22. Bharat metkar Pal SC, Veena Kasture, Sanjay Kasture. Antidepressant activity of Nardostachys Jatamansi DC. Ind J Nat Prod. 1999;15(2):10-13.

23. Rao VS, Rao A, Karanth KS. Anticonvulsant and neurotoxicity profile of Nardostachys Jatamansi in rats. J Ethanopharmacol. 2005;102(3):351-356.

24. Arora RB, Madan BR. Antiarrythmics-Antiarrythmic activity of Nardostachys Jatamansi (an indigenous drug). Ind J Med Res. 1956;44(2):259-269.

25. Subashini R, Yogeeta S, Gnanapragasam A, Devaki T. Protective effect of Nardostachys Jatamansi on oxidative injury and cellular abnormalities during doxorubicin-induced cardiac damage in rats. J Pharma Pharmacol. 2006;58(2):257-262.

26. Joshi H, Parle M. Nardostachys jatamansi improves learning and memory in mice. J Med Food. 2006;9(1):113-118. 
27. Ahamad M, Saleem S, Ahamad AS, et al. Neuroprotective effect of Withania sominifera on 6-hydroxydopamine induced Parkinsonism in rats. Hum Exp Toxicol. 2005;24(3):137-147.

28. Ali A, Dua Y, Siddiqui AW, Sultana S, Rafiullah MRM. Inhibition of benzoyl peroxide-induced cutaneous oxidative stress, toxicity and ear edema in mice by Nardostachys Jatamansi. Pharmaceutical Biol. 2005;43(6):533-539.

29. Ahmad M, Yousuf S, Khan BM. Attenuation by Nardostachys jatamansi of 6-hydroxydopamine-induced parkinsonism in rats: behavioral, neurochemical, and immunohistochemical studies. Pharmacol Biochem Behav. 2006;83(1):150-160.

30. Ecobichnon DJ. The Basis of Toxicity Testing. 2nd Ed. New York, NY: CRC Press; 1997.

31. Williams PD, Pergaman E. Comprehensive Toxicology. 2nd Ed. Oxford, UK: Pergamon Press; 1984.

32. Mukherjee KL. Medical Laboratory Technology. 1st Ed. New Delhi, India: Tata McGraw Hill; 1989.

33. Chopde CT, Khisti RT, Mandane SN. Haloperidol-induced catalepsy: A model for screening antidepressants effective in treatment of depression with Parkinson's diseases. Ind J Exp Biol. 1997;35:1297-1301.

34. Kulkarni SK, Anil Kumar S. Effect of BR-16A $\left(\right.$ Mentat $\left.^{\mathbb{R}}\right)$, a poly herbal formulation on drug induced catalepsy in mice. Ind J Exp Biol. 2006;44:45-48.

35. Niehaus WG, Samuelson B. Formation of malondialdehyde from phospholipid arachidonate during microsomal lipid peroxidation. Eur J Biochem. 1968;6:126-130.

36. Sinha KA. Colorimetric assay of catalase. Anal Biochem. 1972;47: 389-394.

37. Beauchamp C, Fridovich I. Superoxide dismutase:Improved assays and an assay applicable to acrylamide gels. Anal Biochem. 1971;44:276-87.
38. Peterson GL. Review of the folin phenol protein quantification method of Lowry, Rosenbrough, Farr and Randall. Anal Biochem. 1979;100:201-220.

39. Ellman GL. Tissue sulfhydryl groups. Arch Biochem Biophys. 1959;82:70-77.

40. Skaper SD, Floreani M, Ceccon M, Facci L, Giusti P. Excitotoxicity, oxidative stress, and the neuroprotective potential of melatonin. Ann NY Acad Sci. 1999;890:107-118.

41. Gilman SC, Bonner MJ, Pellmar TC. Effect of oxidative stress on excitatory aminoacid release by cerebral cortical synaptosomes. Free Rad Med Biol. 1993;15:671-675.

42. Coyle JT, Puttfarcken P. Oxidative stress, glutamate, and neurodegenerative disorders. Science. 1993;262:689-695.

43. Gilgun-Sherki Y, Rosenbaum Z, Melamed E, Offen D. Antioxidant therapy in acute central nervous system injury: the current state. Pharmacol Rev. 2002;54:271-284.

44. Naidu PS, Singh A, Kulkarni SK. Effect of Withania somnifera root extract on haloperidol induced orofacial dyskinesia: Possible mechanism of action. J Med Food. 2003:6;107-114.

45. Aragno M, Brignardello E, Tamagno O, Boccuzzi G. Dehydroeppiandrosterone administration prevents the oxidative damage induced by acute hyperglycemia in rats. J Endocrinol. 1997;155:233-240.

46. Tripathi YB, Ekta T, Anil U. Antilipid peroxidative property of Nardostachys Jatamansi. Ind J Exp Biol. 1996;34:1150-1151.

47. Salim S, Ahmad M, Zafar KS, Ahmad AS, Islam F. Protective effect of Nardostachys jatamansi in rat cerebral ischemia. Pharmacol Biochem Behav. 2003;74(2):481-486.

48. Prabhu V, Karanth KS, Rao A. Effects of Nardostachys jatamansi on biogenic amines and inhibitory amino acids in the rat brain. Planta Med. 1994;60(2):114-117.
International Journal of General Medicine

\section{Publish your work in this journal}

The International Journal of General Medicine is an international, peer-reviewed open-access journal that focuses on general and internal medicine, pathogenesis, epidemiology, diagnosis, monitoring and treatment protocols. The journal is characterized by the rapid reporting of reviews, original research and clinical studies across all disease areas.

\section{Dovepress}

A key focus is the elucidation of disease processes and management protocols resulting in improved outcomes for the patient. The manuscript management system is completely online and includes a very quick and fair peer-review system. Visit http://www.dovepress.com/ testimonials.php to read real quotes from published authors. 